\title{
Pengaruh Kualitas Pelayanan, Harga, dan Citra Merek terhadap Kepuasan Pelanggan Jasa Transportasi Online Grab
}

\author{
Steffany Revina Wulandari \\ stefanyrevina@gmail.com \\ Sekolah Tinggi Ilmu Ekonomi Surakarta \\ Ari Susanti \\ santisties@gmail.com \\ Sekolah Tinggi Ilmu Ekonomi Surakarta
}

\begin{abstract}
Abstrak
This study aims to analyze the effect of service quality, price, and brand image on customer satisfaction with the services of the Gra,b online motorcycle taxi application. The sample in this study was 109 users of transportation services from online motorcycle taxis Grab using the purposive sampling method. Furthermore, the data were analyzed using multiple linear regression to determine the relationship between the variables of service quality, price and brand image on customer satisfaction. The results of research data analysis show that the price variable, brand image partially has a positive and significant effect on customer satisfaction for Grab's online transportation services, while service quality partially has no significant effect on customer satisfaction for Grab's online transportation services.
\end{abstract}

Keywords : brand image, customer satisfaction, price, service quality

\section{Pendahuluan}

Perkembangan transportasi pada saat ini sudah sangat pesat, termasuk juga jasa transportasi ojek, di mana jasa transportasi ojek ini sudah didukung oleh kemajuan teknologi berupa jaringan internet. Sebelum masuknya jaringan internet ke dalam inudustri jasa transportasi ojek, secara umum jasa ojek hanya dapat ditemukan di pangkalan ojek saja. Konsumen harus berjalan ke pangkalan terlebih dahulu untuk bisa menggunakan jasa transportasi ojek. Pada saat itu, tidak ada standar atau ukuran baku yang digunakan untuk tarif ojek. Tarif yang di tawarkan pun akan beragam sesuai dengan kesepakatan antara dari sopir ojek dengan konsumen yang bersangkutan. Seiring dengan berkembangnya teknologi, maka pada tahun 2012 muncullah jasa ojek online pertama di Indonesia, yakni Go-jek, di mana perusahaan ini hadir dengan menawarkan berbagai kemudahan bagi masyarakat. Selain melayani penumpang, Go-jek juga menawarkan pelayanan pengantaran barang, pembelian makanan, dan masih banyak lagi pelayanan lain yang ditawarkan oleh Go-Jek. Pada tahun 2014, muncul pesaing baru pada industry serupa yang menawarkan fasilitas yang sama dengan Go-jek, yaitu Grab (Edy Susanto, 2019). Pada awal masuknya Grab ke Indonesia, perusahaan ini memberikan banyak promo harga yang menarik untuk dapat mengambil hati masyarakat, dan hal tersebut cukup efekif karena banyak pengguna Go-jek yang beralih menggunakan jasa Grab.

Hildayanti, dkk (2018) menjelaskan bahwa peranan dari pelayanan sangat signfikan terhadap kepuasan pelanggan. Berdasarkan Peraturan Menteri Perhubungan Nomor : PM 12 Tahun 2019 tentang Perlindungan Keselamatan Pengguna Sepeda Motor Yang Digunakan Untuk Kepentingan Masyarakat, pemerintah menetapkan besaran tarif batas bawah (TBB) jasa ojek yang sebelumnya ditetapkan Rp 2.000 per kilometer, naik menjadi Rp 2.250 per kilometer. Untuk tarif batas atas (TBA) yang semula Rp 2.500 per kilometer, naik menjadi Rp 2.650 per kilometer. Kenaikan tariff untuk jasa ojek ini diharapkan dapat diikuti oleh peningkatan kualitas pelayanan, karena selain pelayanan, harga yang ditetapkan juga dapat mempengaruhi tingkat kepuasan konsumen. 
Berdasarkan informasi yang didapat dari beberapa orang konsumen Grab, ada berbagai hal yang membuat konsumen lebih tertarik untuk menjadi pelanggan Grab daripada Gojek. Menurut pendapat konsumen Grab, aplikasi Grab banyak menawarkan kode promo yang selalu membuat konsumen tertarik, dari segi harga pun ada beberapa produk yang lebih murah melakukan pembelian melalui jasa Grab dari pada Go-jek. Dilihat dari tingkat kecepatan dalam hal daya akses aplikasi, Grab lebih cepat dibandingkan dengan Go-jek. Dalam hal pelayanan, konsumen merasa lebih nayaman untuk menggunakan Grab Car ataupun Grab Bike karena sejak adanya pandemi virus Covid-19, Grab memberikan pembatas antara pengemudi dan pelanggan sehingga membuat konsumen merasa lebih aman. Berdasarkan wawancara awal yang dilakukan kepada beberapa orang konsumen mengenai tanggapan mereka atas pelayanan jasa ojek online Grab, konsumen mengaku merasa cukup puas. Selain driver yang ramah, sebagian besar driver Grab juga dinilai bersih dan wangi. Belum lagi promo yang di tawarkan oleh Grab yang cukup menggiurkan bagi para pengguna jasa ojek online di Indonesia. Pada tahun 2020, konsumen lebih banyak menggunakan jasa Grab dibandingkan dengan Go-jek. Berdasarkan survey yang dilakukan atas pengguna atau konsumen jasa ojek online yang dilakukan pemilihan secara acak sebanyak 280 konsumen dan 40 pengemudi dalam skala nasional menyebutkan bahwa $58 \%$ dan $62 \%$ responden memilih jasa ojek online Gojek sebagai alat transportasi selama 3 dan 6 bulan terakhir, sedangkan $61 \%$ dan $75 \%$ menyebutkan responden memilih jasa ojek online Grab sebagai alat transportasi selama 3 dan 6 bulan terakhir.

Faktor yang pertama untuk mencapai kepuasan pelanggan yaitu kualitas pelayanan. Kualitas pelayanan merupakan kemampuan dalam memuaskan kebutuhan konsumen yang tersirat atau dinyatakan dari keseluruhan sifat serta ciri suatu pelayanan atau produk (Kotler dan Keller, 2017). Faktor ke dua yaitu harga, yaitu segala bentuk dari biaya yang dikeluakan seseorang untuk memanfaatkan, memperoleh, miliki jumlah kombinasi dari barang atau jasa suatu produk (Hasan, 2013). Faktor ke tiga yang menjadi pendukung kepuasan pelanggan adalah citra merk. Menurut Kotler dan Keller (2017), citra merek adalah citra dari suatu merek produk yang akan dipakai dan dikonsumsi dari persepsi konsumen. Menciptakan kepuasan konsumen melalui ketiga factor tersebut bukanlah hal yang mudah dalam industry jasa transportasi online. Masing-masing dari ketiga faktor tersebut memiliki kendala dalam aktualisasinya. Dari segi harga, salah satu cara yang ditawarkan untuk menarik hati pelanggan adalah dengan cara memberikan diskon pembelian yang akan mengakibatkan keuntungan yang lebih sedikit bagi perusahaan. Dari segi kualitas pelayanan, tidak sedikit ditemukan driver yang masih sulit mengaplikasikan map atau membaca peta yang membuat pengantaran menjadi lebih lama yang selanjutnya akan berpengaruh pada citra merk perusahaan Grab.

Berdasarkan uraian di atas peneliti ingin menganalisis kinerja Grab yang langsung dapat bersaing secara ketat dengan Go-jek yang lebih dahulu hadir dan menjadi salah satu perusahaan transportasi online yang langsung berkembang secara pesat di awal kemunculannya. Peneliti tertarik meneliti jasa transportasi Grab karena sebagai pendatang baru, Grab dengan cepat dapat menarik hati masyarakat. Selain itu, dengan kualitas pelayanan yang sama dengan Gojek, Grab berani memberikan diskon harga yang cukup besar sehingga membuat pelanggan tertarik untuk menggunakan jasanya. Untuk mengetahuinya maka peneliti melakukan analisis terhadap kualitas pelayanan, harga, serta citra merek yang ditawarkan kepada pelanggan yang mampu menciptakan kepuasan pelanggan pada suatu produk barang ataupun jasa. Penelitian ini dilakukan dengan metode yang berbeda, yaitu dengan membagikan kuisioner tidak hanya pada konsumen Grab saja, tetapi juga pada pelanggan Grab sehingga peneliti bisa melakukan perbandingan persepsi terhadap kualitas pelayanan, perbedaan harga, dan citra merka baik dari sudut pandang pengguna jasa transportasi ojek online Grab, maupun dari sudut pandang driver sendiri. 


\section{Landasan Teori}

\subsection{Kualitas Pelayanan}

Kualitas pelayanan meruapakan ujung tombak bagi perusahaan karena berpengaruh pada kepuasan konsumen, dan munculnya kepuasan tersebut apabila pelayanan yang di berikan baik (Mulyapradana \& Lazulfa, 2018). Harapan pelanggan terhadap kualitas pelayanan adalah di mana perusahaan penyedia jasa pelayanan dapat memahami kebutuhan pelanggan serta menjaga hubungan yang baik dengan pelanggan yang bersangkutan (Shartanto, Djatnika, Ruhadi, \& Triyuni, 2017). Kotler dan Keller (2017) mengemukakan 5 indikator yang dominan atau menjadi penentu dari kualitas pelayanan, antara lain :

a. Kehandalan, yaitu ketika suatu perusahaan mampu menimbulkan rasa percaya, cermat dan konsisten dalam memberikan pelayanan yang sesuai dengan apa yang telah disepakati, terpercaya dan akurat.

b. Wujud, yaitu peralatan, penyampaian dalam berkomunikasi yang baik dan penampilan fisik penyedia pelayanan yang menunjang

c. Daya tanggap, yaitu kemauan dari pengusaha dan pegawai penyedia jasa pelayanan untuk membantu konsumen dengan tanggap dan cepat serta mampu mengatasi dan mendengar keluhan konsumen.

d. Jaminan, yaitu kemampuan pegawai untuk memunculkan rasa percaya dan keyakinan terhadap janji yang disampaikan kepada konsumen

e. Empati, yaitu kesediaan pengusaha dan karyawan secara pribadi untuk lebih memberikan kepedulian kepada pelanggan.

\subsection{Harga}

Salah satu variable penting dalam pemasaran produk adalah harga. Di satu sisi, harga dapat menunjukkan kualitas produk yang ditawarkan, dan di sisi lain harga harus dapat dijangkau oleh pasar yang menjadi sasaran perusahaan. Menurut Setiowaty \& Winarningsih, (2017), harga merupakan jasa atau nilai yang dibayarkan dalam jumlah tertentu yang diberikan oleh konsumen dalam rangka sebagai pertukaran untuk mendapatkan manfaat dari menggunakan atau memiliki jasa atau barang. Salah satu indikator nilai adalah harga, bila harga suatu produk tinggi, secara umum manfaat atau nilai yang ditawarkan melalui representasi produk juga akan tinggi. Semakin tinggi harga suatu produk akan memberikan nilai yang lebih tinggi pula bagi konsumennya. Menurut Gofur (2019), konsumen dapat mempersepsikan jasa atau produk berdasarkan melihat dan menyesuaikan harga berdasarkan nilai dan pengorbanan yang diterima konsumen setelah melakukan pembelian. Menurut Alma (2011), ada 4 (empat) indikator yang menjadi ciri dari daya saing harga dengan menyesuaikan harga dengan kualitas produk, antara lain :

a. Keterjangkauan harga, yaitu daya beli konsumen yang menjadi dasar dalam aspek penetapan harga oleh penjual atau produsen.

b. Kesesuaian harga dengan kualitas produk, yaitu kualitas dari suatu produk yang didapat oleh konsumen menjadi aspek dari penelitian harga oleh penjual atau produsen.

c. Daya saing harga, yakni persaingan harga yang ditawarkan penjual ataupun produsen lain atas produk atau jasa yang sama.

d. Kesesuaian harga dengan manfaat, yakni kesesuaian manfaat yang diperoleh konsumen atas barang atau jasa yang telah dibeli sebagai dasar dari penetapan harga yang dilakukan oleh penjual atau produsen.

\section{3. $\quad$ Citra Merek}

Menurut Kotler dan Keller (2017), citra merek adalah asosiasi merek yang menjadi refleksi yang ada pada pikiran konsumen yang memunculkan persepsi konsumen terhadap suatu merek. Persepsi yang baik akan muncul jika konsumen merasakan kepuasan atas suatu jasa atau produk. Menurut Simon (2016), tingginya tingkat kepuasan konsumen didasarkan pada persepsi yang semakin membaik dibenak konsumen terhadap citra merek dari suatu perusahaan. Menurut Sondakh (2015), citra merek adalah pengalaman masa lalu dan bentuk infromasi yang di peroleh konsumen terhadap suatu merek yang berupa representasi dari 
semua persepsi konsumen terhadap merek. Merek memiliki citra yang merupakan hubungan antara perilaku yang menunjukkan tingkat preferensi dan keyakinan konsumen atas suatu produk. Banyak perusahaan dapat meningkatkan laba atau keuntungan dengan memberikan kepuasan pada merek. Pembentukan citra merek bagi sebuah produk sangatlah penting, karena akan berpengaruh terhadap sikap dan perilaku konsumen pada keputusan pembeliannya. Jadi kepuasan pelanggan dapat timbul dari citra merek yang baik. Menurut Alexander (2014), ada 3 (tiga) indikator citra merek, antara lain :

a. Atribut produk, yaitu beberapa hal yang memiliki kaitan dengan merek seperti rasa,, bentuk, kemasan, dan yang lainnya.

b. Keuntungan konsumen, yaitu suatu kegunaan yang dimiliki oleh merek.

c. Kepribadian merek, yaitu asosiasi terhadap manusia sebagai konsumen yang menunjukkan kepribadian dari suatu merek.

\subsection{Kepuasan Pelanggan}

Menurut Tjiptono (2014), kepuasan atau ketidakpuasan pelanggan menunjukkan tanggapan konsumen terhadap hasil dari rasa puas atau ketidakpuasan atas keinginan yang sebelumnya, ataupun kinerja yang lain dari produk yang di rasakan setelah melakukan pemakaian. Menurut Setiono (2012), kepuasan pelanggan merupakan rasa senang, bangga ataupun rasa puas yang dirasakan pengguna ketika mendapatkan suatu jasa atau produk yang diberikan sesuai dengan yang diharapkan. Menurut Sangadji \& Sopiah (2013), terdapat 4 (empat) indikator kepuasan pelanggan, antara lain :

a. Perasaan puas (puas dalam artian pada pelayanan dan produknya), yaitu rasa yang muncul dalam diri konsumen ketika menggunakan produk yang berkualitas dan saat menerima pelayanan yang baik baik.

b. Selalu membeli produk, yaitu bila pelanggan merasakan harapan yang di inginkan tercapai, maka kesetiaan untuk terus menggunakan dan membeli produk akan tercipta.

c. Akan merekomendasikan kepada orang lain, yaitu munculnya pelanggan baru bagi perusahaan karena adanya promosi secara tidak langsung oleh pelanggan sebelumnya yang merasakan kepuasan ketika menggunakan jasa atau produk suatu perusahaan.

d. Terpenuhinya harapan konsumen setelah melakukan pembelian, yaitu perasaan atau harapan yang muncul dari pelanggan setelah melakukan pembelian produk dengan kualitas yang sesuai dengan yang diharapkan.

\section{5. $\quad$ Hipotesis}

Penelitian ini memiliki rumumusan hipotesis sebagai berikut :

a. Kualitas pelayanan berpengaruh positif dan signifikan terhadap kepuasan pelanggan jasa transportasi online Grab

b. Harga berpengaruh positif dan signifikan terhadap kepuasan pelanggan jasa transportasi online Grab

c. Citra merek berpengaruh positif dan signifikan terhadap kepuasan pelanggan jasa transportasi online Grab

\section{Metode Penelitian}

Objek dalam penelitian ini adalah konsumen Grab, yang dianggap peneliti sangat tepat untuk menjadi responden dan narasumber dalam memberikan penilaian. Penelitian ini menggunakan metode survei dalam pendekatan kuantitatif, dan untuk mengukur instrument penelitian menggunakan skala likert. Metode penelitian suvei merupakan metode untuk memperoleh tanggapan responden yang digunakan untuk menjelaskan hubungan kausal antar variable dan pengujian hipotesis. Pengumpulan data dalam metode survey dapat dilakukan dengan menggunakan instrument ataupun wawancara (Sugiyono, 2012). Untuk mengukur pernyataan yang mewakili pendapat dari responden yang terdapat di dalam kuesioner dibuat dalam skala 1-5. Alat uji hipotesis dan teknik analisis data dalam penelitian ini meliputi : (Ghozali, 2013) 
a. Uji validitas dipergunakan untuk menjadi alat ukur valid tidaknya sebuah kuesioner. Bila pernyataan dari kuisioner mampu ketika diukur oleh kuisioner tersebut maka kuisioner tersebut dapat dikatakan valid

b. Uji reliabilitas, merupakan alat ukur dari pernyataan yang menjadi indikator dari konstruk atau variabel. Bila jawaban dari responden konsisten atau stabil maka instrument tersebut dapat di katakan reliabel

c. Uji Normalitas bertujuan untuk melakukan pengujian data yang terdistribusi normal atau tidak. Bila nilai residual yang mendekati normal atau berdistribusi normal maka model regresi dikatakan baik

d. Uji Multikolonieritas memiliki tujuan untuk menguji ditemukannya korelasi atau tidak antara variabel independen dalam model regresi. Bila tidak terjadi korelasi diantara variabel independen maka model regresi dikatakan baik

e. Uji Heteroskedastisitas bertujuan untuk melakukan pengujian ketidaksamaan variance dalam model regresi dari residual antara pengamatan dengan pengamatan lain. Bila terjadi atau yang tidak terjadi heteroskedastisitas maka model regresi dikatakan baik.

Sekaran, dkk (2017) mendiskripsikan populasi sebagai sampel statistik yang didasarkan pada kejadian dari hal menarik ataupun kejadian dari sekelompok orang yang dibuat oleh peneliti. Responden yang digunakan dalam penelitian adalah semua pengguna aplikasi Grab di seluruh Indonesia dengan rata-rata usia 18-59 tahun yang menggunakan jasa ojek online Grab lebih dari 5 (lima)kali. Sampel dalam penelitian ini berjumlah 109 orang. Penentuan jumlah sampel tersebut didasarkan atas pendapat Roscoe dalam Sugiyono (2012), yang menyatakan bahwa dalam penelitian dengan besar populasi yang tidak pasti dapat menggunkan sampel sebesar 30 sampai dengan 500. Pemilihan sampel menggunakan teknik accidental, yaitu memilih sampel dari anggota populasi yang secara kebetulan ditemui pada saat penelitian dilakukan.

\section{Analisis dan Pembahasan}

\subsection{Karakteristik Responden}

a. Karakteristik Responden Berdasarkan Usia

Berdasarkan usia, responden yang memiliki usia dari 15 tahun sampai 25 tahun berjumlah 36 responden (33\%), 26 tahun sampai 35 tahun berjumlah 56 responden (51\%), dan usia di atas 36 tahun berjumlah 17 responden (16\%). Diketahui usia responden yang mendominasi yaitu yang memiliki usia antara 26 sampai 35 tahun yang berjumlah 56 orang (51,38\%), selanjutnya usia responden 15 sampai 25 tahun sebanyak 36 orang (33,03\%), kemudian usia 46 sampai 59 tahun sebanyak 17 orang $(15,60 \%)$.

b. Karakteristik Responden Berdasarkan Jenis Kelamin

Berdasarkan jenis kelamin, responden penelitian yang mendominasi adalah yang berjenis kelamin perempuan. Pengguna Grab yang berjenis kelamin perempuan berjumlah 69 responden $(63,30 \%)$ dan laki-laki berjumlah 40 responden $(36,70 \%)$.

\subsection{Deskripsi Variabel Penelitian}

\section{a. Rekapitulasi Jawaban Responden}

Hasil dari variabel kualitas pelayanan, rata-rata pelanggan Grab yang menjawab sangat setuju sebesar 43,94\%, setuju $30.73 \%$, netral $12,57 \%$, tidak setuju $7,43 \%$ dan yang menjawab sangat tidak setuju 3,32\%. Berarti sebagian besar responden mempersepsikan sangat setuju bahwa kualitas pelayanan Transportasi online grab memuaskan.

Hasil dari variabel harga, responden menanggapi mengenai harga yang ditentukan di aplikasi Grab, rata-rata responden yang menjawab sangat setuju sebesar 34,29\%, setuju 36.24\%, netral 14,79\%, tidak setuju 8,94\% dan yang menjawab sangat tidak setuju 5,73\% responden. Berarti sebagian besar responden mempersepsikan bahwa harga berpengaruh dalam memilih transportasi online Grab.

Hasil dari variabel citra merek, responden menjawab mengenai citra merek yang dibangun oleh Grab rata-rata responden yang menjawab sangat setuju sebesar 27,06\%, setuju 36.85\%, netral 21,71\%, tidak setuju 9,79\% dan yang menjawab sangat tidak 
setuju 4,59\%. Berarti sebagian besar responden mempersepsikan bahwa citra merek memiliki pengaruh dalam memilih transportasi online Grab.

Hasil dari variabel kepuasan pelanggan, responden menjawab mengenai kepuasaan mengunakan jasa Grab di mana rata-rata responden yang menjawab sangat setuju sebesar 25,46\%, setuju 38.53\%, netral 22,59\%, tidak setuju 8,83\% dan yang menjawab sangat tidak setuju 4,59\%. Berarti sebagian besar persepsi dari responden adalah kepuasan pelanggan berpengaruh dalam memilih transportasi online Grab.

Berdasarkan hasil jawaban responden atas kuesioner yang diberikan dapat diektahui bawha responden yang merasa tidak puas atas pelayanan yang diberikan oleh jasa transportasi ojek online Grab ada;ah sebesar 5,06\%. Meskipun persentase tersebut dapat dikatakan cukup kecil, namun pihak Grab harus tetap melakukan perbaikan agar responden yang belum merasa puas dengan pelayanan Grab dapat dikurangi.

b. Uji Validitas

Pengujian validitas data dikriteriakan dengan cara melakuakan perbandingan $r$ hitung dan $r$ tabel $(0,195)$. Pernyataan untuk variabel kualitas pelayanan berjumlah 10 item, pertanyaan untuk variabel harga berjumlah 8 item, pertanyaan untuk variabel citra merek berjumlah 6 item, dan pertanyaan untuk variable kepuasan pelanggan berjumlah 8 item pertanyaan yang diajukan kepada 109 responden yang hasilnya dinyatakan valid dan dapat digunakan untuk meneruskan penelitian.

c. Uji Reabilitas

Kesimpulan yang dapat dilakukan dari pengujian reliabilitas data dari ketiga variabel mempunyai Nilai Cronbach's diatas 0,6 pada taraf nyata alpha $(\alpha)=5 \%$. Maka kesimpulan dari seluruh item pernyataan menyatakan bahwa dapat digunakan sebagai alat ukur karena hasilnya reliabel

Tabel 1. Hasil Uji Reabilitas

\begin{tabular}{lcc}
\hline \multicolumn{1}{c}{ Variabel } & $\begin{array}{c}\text { Cronbach's } \\
\text { Alpha }\end{array}$ & Keterangan \\
\hline Kualitas Pelayanan & 0,984 & Reliabel \\
Harga & 0,955 & Reliabel \\
Citra Merek & 0,954 & Reliabel \\
Kepuasan Pelanggan & 0,939 & Reliabel \\
\hline
\end{tabular}

Sumber : Data Primer diolah, 2021

d. Uji Normalitas

Tabel 2. Hasil Uji Normalitas

Unstandardized

Residual

Asymp. Sig. (2-tailed)

$0,200 \mathrm{c}, \mathrm{d}$

Sumber : Data Primer diolah, 2021

Dapat disimpulkan bahwa data di atas berdistribusi normal, karena hasil uji normalitas menunjukkan hasil Asymp.Sig senilai 0,200 lebih besar dari 0,05.

e. Uji Multikolonieritas

Dengan mengesampingkan variabel dependen dalam model regresi maka nilai dari tolerance menjelaskan ragam variabel independen di jelaskan oleh variabelvariabel independen lainnya. Tujuan pengujian dari uji multikoliniearitas adalah agar peneliti mengetahui hubungan kuat antara variabel bebas untuk model dari regresi, pengujian ini melalui besarnya koefisien korelasi dengan variabel bebas. Dapat diketahui dari ini VIF (varian inflation factor) yang memiliki nilai toleransi tidak lebih dari 1 dan mayoritas dari variabel masih sekitar 1, sehingga diantara variabel bebas tidak dinyatakan terdapat multikolonieritas seperti gambar dari tabel dibawah ini 


\begin{tabular}{lcc}
\multicolumn{3}{c}{ Tabel 3. Hasil Uji Multikolinearitas } \\
\hline & \multicolumn{2}{c}{ Collinearity } \\
& Statistics \\
\cline { 2 - 3 } & $\begin{array}{c}\text { Toleranc } \\
\text { e }\end{array}$ & VIF \\
\hline Kualitas Pelayanan $\left(\mathrm{X}_{1}\right)$ & 0,233 & 4,289 \\
Harga $\left(\mathrm{X}_{2}\right)$ & 0,147 & 6,807 \\
Citra Merek $\left(\mathrm{X}_{3}\right)$ & 0,139 & 7,212 \\
\hline Sur
\end{tabular}

Sumber : Data Primer diolah, 2021

Informasi dari tabel 3 menyatakan bahwa semua nilai tolerance variabel bebas di atas $10 \%$, begitu juga dengan variable kualitas pelayanan yaitu sebesar $23,3 \%$ atau 0,233, variabel Harga 14,7\% atau 0,147 dan Citra Merek 13,9\% atau 0,139. Maka kesimpulan bahwa semua variabel $\mathrm{X}$ tidak terdapat multikoleniaritas sehingga model dari regresi tidak terjadi multikoliniearitas.

f. Uji Heteroskedastisitas

Cara mendeteksi terdapatnya heteroskedastisitas adalah dengan melihat grafik scatterplot, terlihat atau tidak pola tertentu. Uji scatterplot menghasilkan uji heteroskedastisitas yang mendeteksi bahwa tidak adanya pembentukan titik yang berpola secara teratur (melebar dan bergelombang lalu menyempit), atau penyebaran titik di atas dan di bawah dari 0 pada sumbu Y. Jadi kesimpulannya adalah tidak adanya masalah heteroskedastisitas.

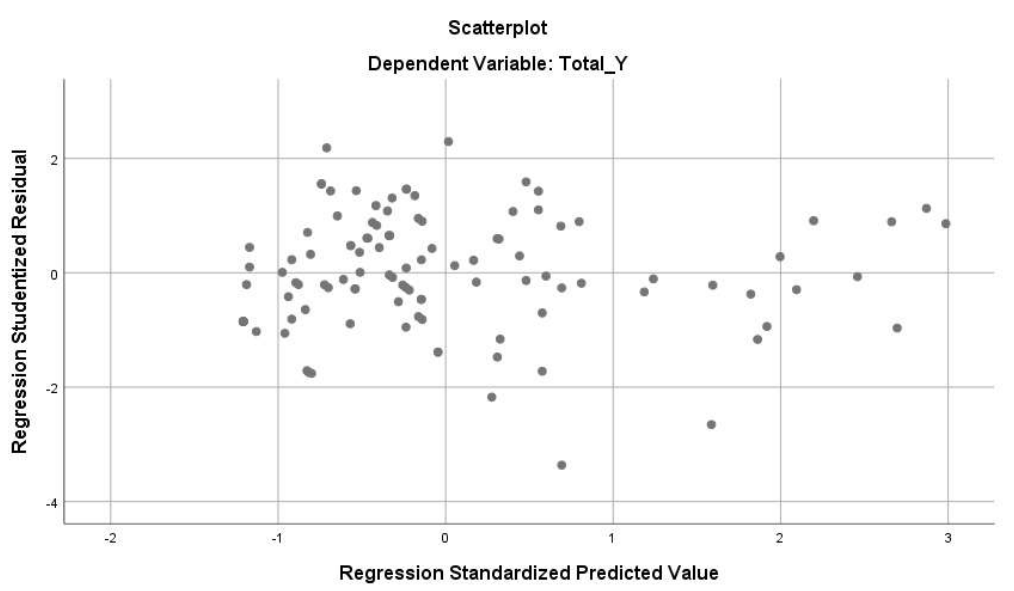

Berdasarkan output data scatterplot diatas di ketahui bahwa :

1) Penyebaran titik data berada di bawah dan di atas atau disekitar 0

2) Keberadaan titik-titik yang tidak berkumpul hanya berada di bawah atau di atas saja

3) Penyebaran titik-titik tidak membentuk suatu gelombang pola yang melebar lalu menyempit lalu kembali melebar

4) Penyebaran darii titik-titik data tidak terbentuk suatu pola

Dapat disimpulakan model regresi baik dan ideal karena tidak adanya masalah heteroskedastistas. 


\subsection{Uji Hipotesis}

\subsubsection{Regresi Berganda}

Tabel 4. Hasil Uji Regresi Berganda

\begin{tabular}{lc}
\hline \multicolumn{1}{c}{ Variabel } & Unstandardized Beta Coefficients \\
\hline (Constant) & 3,682 \\
Kualitas Pelayanan & 0,127 \\
Harga & 0,507 \\
Citra Merek & 0,243 \\
\hline
\end{tabular}

Sumber : Data Primer diolah, 2021

Hasil dari tabel di atas dapat disimpulkan model regresi linear berganda pada analisis ini yaitu $\mathrm{Y}=3,682+0,127 \mathrm{X} 1+0,507 \mathrm{X} 2+0,243 \mathrm{X} 3$. Menurut persamaan dari regresi diatas, interpretasi dari koefisien setiap variabel antara lain :

a. Dari nilai konstanta sebesar 3,682 terlihat bahwa bila variabel kualitas pelayanan $\left(\mathrm{X}_{1}\right)$, harga $\left(\mathrm{X}_{2}\right)$, dan citra merek $\left(\mathrm{X}_{3}\right)$ dinilai konstan, maka besaran kepuasan pelanggan adaalah 3,682 .

b. $B 1=0,127$, bila variabel kualitas pelayanan $\left(X_{1}\right)$ naik sebesar satuan tersebut, maka kepuasan konsumen akan naik sebesar 0,127 satuan atau dapat dijelaskan bahwa variabel kepuasan pelanggan $(\mathrm{Y})$ akan meningkat jika kualitas pelayanan $\left(\mathrm{X}_{1}\right)$ meningkat.

c. $B 2=0,507$, bila variabel harga $\left(X_{2}\right)$ naik sebesar satuan tersebut, maka kepuasan konsumen akan naik sebesar 0,507 satuan atau dapat dijelaskan bahwa variabel kepuasan pelanggan $(\mathrm{Y})$ akan meningkat jika harga $\left(\mathrm{X}_{2}\right)$ meningkat.

d. $B 3=0,243$, bila variabel citra merek $\left(X_{3}\right)$ naik sebesar satuan tersebut, maka kepuasan konsumen akan naik sebesar 0,243 satuan atau dapat dijelaskan bahwa variabel kepuasan pelanggan $(\mathrm{Y})$ akan meningkat jika citra merek $\left(\mathrm{X}_{3}\right)$ meningkat.

\subsubsection{Uji t}

Tabel 5. Hasil Uji t

\begin{tabular}{lcc}
\hline \multicolumn{1}{c}{ Variabel } & t & Sig. \\
\hline Kualitas Pelayanan & 1,672 & 0,097 \\
Harga & 5,508 & 0,000 \\
Citra Merek & 2,345 & 0,021
\end{tabular}

Sumber : Data Primer diolah, 2020

Diketahui hasil dari uji t dimaksudkan untuk mengetahui pengaruh (X1) Kualitas Pelayanan, (X2) Harga, (X3) Citra Merek secara parsial terhadap (Y) Kepuasan Pelanggan.

a. Hasil dari uji t hitung variabel kualitas pelayanan $\left(X_{1}\right)$ yaitu $(1,672)$ dari pada $t$ tabel $(0,195)$ atau dapat diketahui dari nilai signifikasi 0,097 $\alpha=0,05$. Maka Ho diterima dan Ha ditolak, artinya kepuasan pelanggan tidak dipengaruhi secara signifikan oleh kualitas pelayanan.

b. Hasil dari uji thitung variabel harga $\left(\mathrm{X}_{2}\right)$ diketahui yaitu $(5,508)$ daripada $t$ tabel $(0,195)$ atau dapat diketahui dari nilai signifikasi $0,000<\alpha=0,05$. Maka Ho ditolak dan Ha diterima, artinya kepuasan pelanggan dipengaruhi secara signifikan oleh harga.

c. Hasil dari uji thitung variable citra merek (X3) yaitu $(2,345)$ daripada t tabel $(1,984)$ atau dapat diketahui dari nilai signifikasi $0,021<\alpha=0,05$. Maka Ho ditolak dan Ha diterima, artinya kepuasan pelanggan dipengaruhi secara signifikan oleh citra merek. 


\subsubsection{Koefisien Determinasi}

\begin{tabular}{c|c|c|c}
\multicolumn{4}{c}{ Tabel 9. Uji Koefisien Determinasi } \\
\hline $\mathrm{R}$ & $\begin{array}{c}\mathrm{R} \\
\text { Square }\end{array}$ & $\begin{array}{c}\text { Adjusted R } \\
\text { Square }\end{array}$ & $\begin{array}{c}\text { Std. Error } \\
\text { of the } \\
\text { Estimate }\end{array}$ \\
\hline 0,913 & 0.833 & 0.829 & 2.935 \\
\hline \multicolumn{2}{c}{ Sumber : Data Primer diolah, 2021 }
\end{tabular}

Hasil dari tabel di atas dapat diketahui nilai koefisien determinasi $\left(\mathrm{R}^{2}\right)$ sebesar 0,829 yang menunjukan bahwa $82,9 \%$ yang artinya variabel kepuasan pelanggan dipengaruhi oleh variabel kualitas pelayanan, harga dan citra merek sebesar 82,9\%, sedangkan sisanya yaitu sebesar $17,1 \%$ dipengaruhi oleh faktor lainnya.

\subsection{Pembahasan}

a. Pengaruh dari Kualitas Pelayanan terhadap Kepuasan Pelanggan

Hasil penelitian ini menunjukkan bahwa variabel kepuasan pelanggan tidak dipengaruhi secara signifikan oleh kualitas pelayanan jasa transportasi ojek online Grab. Hasil penelitian ini tidak sejalan dengan penelitian terdahulu yang dilakukan oleh Rivai, Tahir, \& Asnawi (2018) yang melakukan penelitian untuk mengetahui apakah variabel kualitas pelayanan berpengaruh terhadap variabel kepuasan pelanggan. Penelitian ini menggunakan metode purposive sampling sebanyak 200 responden dari mahasiswa FE Universitas Negeri Jakarta yang minimal mempergunakan jasa transportasi online Grab sebanyak dua kali. Hasil yang ditunjukan adalah kepuasan pelanggan dipengaruhi oleh kualitas pelayanan. Kemampuan produsen untuk memenuhi keinginan atau harapan dari konsumen menjadi tolak ukur bagaimana kualitas pelayanan jasa atau produk. Jika konsumen merasakan kepuasan ketika membeli produk maka loyalitas akan tercipta, dan citra dari perusahaan akan baik. Jika kualitas pelayanan dapat sesuai dengan harapan konsumen atau bahkan melebihinya maka bisa dikatakan hal tersebut memenuhi kepuasan pelanggan. Indicator dari kualitas pelayanan ialah keandalan, berwujud, daya tanggap, kepastian dan empati.

\section{b. Pengaruh dari Harga terhadap Kepuasan Pelanggan}

Hasil penelitian ini menunjukkan bahwa variabel harga berpengaruh signifikan dan positif terhadap kepuasan pelanggan pada jasa transportasi ojek online Grab. Terdapat beberapa faktor yang harus dipertimbangkan seperti keterjangkauan harga, kesesuaian harga dengan kualitas barang atau jasa, persaingan harga dan kesesuaian manfaat yang diperoleh dengan harga. Selain itu, harga pasar dari produk/jasa yang sama dan kualitas yang sama pula harus terus dipantau oleh perusahaan karena bila harga yang diberikan perusahaan lebih mahal dari yang harga yang ditentukan oleh pesaing, maka dapat meyebabkan beralihnya konsumen loyal ke pesaing. Hasil penelitian ini sejalan dengan penelitian terdahulu dilakukan oleh Alexander (2014) yang menyatakan bahwa hasil penelitian tersebut menunjukkan bahwa harga berpengaruh positif dan signifikan secara parsial dan simultan terhadap kepuasan konsumen di Hotel Glagah Indah.

c. Pengaruh dari Citra Merek terhadap Kepuasan Pelanggan

Hasil penelitian ini menunjukkan bahwa variabel citra merek berpengaruh signifikan dan positif terhadap kepuasan pelanggan pada jasa transportasi ojek online Grab. Hal ini sesuai dengan penelitian terdahulu yang dilakukan oleh Muttaqin \& Kartini (2020) yang menyatakan bahwa dalam memilih jasa Go-jek di Kecamatan Taman Kabupaten Sidoarjo, citra merek mempunyai pengaruh signifikan terhadap kepuasan pelanggan. Pada bulan Maret 2020, di Indonesia terkena bencana pandemic virus corona atau virus covid-19 sehingga pemerintah memberikan keputusan adanya semi-lockdown yang mewajibkan masyarakat untuk mengurangi bepergian dan melakukan social distancing, bekerja di rumah pun juga menjadi anjuaran dari pemerintah. Hal tersebut berdampak pula pada 
penyedia layanan jasa pesan antar makanan Grab yang menjadi salah satu pilihan masyarakat untuk melakukan social distancing. Oleh karena itu penyedia layanan Grab harus memenuhi faktor citra merek yakni atribut produk, keuntungan konsumen dan kepribadian merek yang baik. Jika terdapat beberapa perubahan yang terjadi pada citra merek, maka kepuasan pelanggan akan turut berubah sesuai dengan berubahnya citra merek dimata pelanggan.

\section{Kesimpulan dan Rekomendasi \\ 5.1. Kesimpulan}

Dalam menentukan jasa transportasi online yang digunakan, berbagai aspek menjadi perimbangan konsumen, antara lain aspek kualitas pelayanan, harga dan citra merek dari jasa transportasi online yang bersangkutan. Dengan adanya hasil pengujian hipotesis pada penelitian ini memiliki beberapa factor yang mempengaruhi kepuasan pelanggan jasa transportasi online Grab. Adapun kesimpulan dari penelitian ini antara lain :

a. Variabe kualitas pelayanan $\left(\mathrm{X}_{1}\right)$. Melalui pengujian secara parsial, hasilnya tidak berpengaruh secara signifikan dalam kriteria kepuasan pelanggan, akan tetapi melalui pengujian hipotesis secara simultan dari kualitas pelayanan memiliki pengaruh terhadap kepuasan pelanggan jasa transportasi online Grab.

b. Variabel harga $\left(\mathrm{X}_{2}\right)$. Pengujian yang dilakuakan secara parsial maupun simultan terhadap variable harga menunjukkan bahwa vairabel ini memiliki pengaruh yang besar terhadap kepuasaan pelanggan karena berada di angka tertinggi dibandingkan dengan variable kualitas pelayanan dan citra merek, sehingga harga memliki pengaruh yang signifikan terhadap kepuasan pelanggan jasa transportasi online Grab.

c. Variabel citra merek $\left(\mathrm{X}_{3}\right)$ mempunyai pengaruh yang positif terhadap kepuasan pelanggan. Dalam hasil pengujian hipotesis, variabel citra merek berada pada tingkat signifikan kedua. Secara tidak langsung citra merek menjadi salah satu indicator penilaian dari konsumen untuk merasakan kepuasan dari produk yang telah dibeli/digunakan.

\section{2. $\quad$ Rekomendasi}

Dari setiap variable yang ada dalam penelitian ini, telah dihasilkan beberapa temuan seperti yang telah diuraikan di atas. Berdasarkan hal tersebut, maka peneliti merekomendasikan beberapa hal sebagai berikut:

a. Dari seluruh variable yang diteliti, terdapat 1 (satu) variable yang tidak berpengaruh signifikan terhadap kepuasan pelanggan, yaitu variable kualitas pelayanan. Meskipun demikian, pihak jasa transportasi online Grab tetap harus meningkatkan kualitas pelayanan yang diberikan kepada konsumen. Karena pada uji simultan, variable kualitas pelayanan bersama-sama dengan variable yang lain memiliki pengaruh yang signifikan terhadap kepuasan pelanggan. Terlebih lagi pada aplikasi Grab terdapat sesi penilaian langsung pelanggan atas kualitas pelayanan yang diberikan setelah menggunakan jasa transportasi online Grab.

b. Berdasarkan hasil penelitian, diketahui bahwa variable harga sangat berpengaruh terhadap kepuasan pelanggan jasa transportasi online Grab. Oleh karena itu, diharapkan kepada pihak jasa transportasi online Grab agar dapat membentuk jalinan hubungan yang baik dengan konsumen melalui pemberian promo seperti potongan harga, bonus atau kupon potongan harga, serta dapat bekerja sama dengan platform penyedia jasa pembayaran non tunai (ovo). Dengan demikian diharapkan pelanggan Grab dapat merasakan kepuasan dalam menggunakan jasa transportasi online Grab.

c. Variabel citra merek harus tetap dipertahankan agar konsumen pengguna jasa transportasi online lebih mengenal Grab sebagai jasa transportasi utama. Jika branding suatu produk berfungsi dengan baik maka akan menambah nilai pada produk layanan jasa transportasi online Grab. 


\section{Daftar Pustaka}

Alma, B. (2011). Manajemen Pemasaran dan Pemasaran Jasa. Bandung: Alfabeta.

B. Alexander, D. (2014). Analisa Pengaruh Citra Merek (Brand Image) dan Kepercayaan Merek (Brand Trust) Terhadap Loyalitas Merek (Brand Loyalty) ADES PT. Ades Alfindo Putra Setia. Jurnal Manajemen Pemasaran Petra, 2(1), 1-9.

Ghozali, I. (2013). Aplikasi Analisis Multivariete. In Badan Penerbit Universitas Dipenegoro.

Gofur, A. (2019). PENGARUH KUALITAS PELAYANAN DAN HARGA TERHADAP KEPUASAN PELANGGAN. Jurnal Riset Manajemen Dan Bisnis (JRMB) Fakultas Ekonomi UNIAT, 4(1), 37-44. https://doi.org/10.36226/jrmb.v4i1.240

Hasan, A. (2013). Marketing dan Kasus-kasus Pilihan. Yogyakarta: CAPS.

Hildayanti, S. K., Marnisah, L., \& ... (2018). Pengaruh Nilai, Kualitas Pelayanan dan Komitmen Organisasi Terhadap Kepuasan Pelanggan Pada PT. Asuransi Kresna Mitra Tbk Cabang Palembang. Jurnal Ilmiah Ekonomi ..., 9(1), 61-70. Retrieved from http://ejournal.uigm.ac.id/index.php/EGMK/article/view/463

Kotler dan Keller. (2017). Manajemen Pemasaran, Edisi 12, Jilid 1, PT.Indeks,. Jakarta. In $e-$ Jurnal Riset Manajemen.

Lydia Setiono. (2012). Engaruh Variabel Trust, Perceived Value, Brand Attitude Dan Customer Satisfaction Terhadap Customer Loyalty Pelanggan McDonalds Drive Thru Di Surabaya. Journal Widya Mandala Catholic University Surabaya.

Mulyapradana, A., \& Lazulfa, A. I. (2018). Tata Kelola Administrasi untuk Meningkatkan Kualitas Pelayanan Administrasi di PT . BAM. Institusi Politeknik Ganseha Medan, 1, 14-24. Retrieved from https://www.jurnal.polgan.ac.id/index.php/juripol/article/download/86/51

Muttaqin, M. Z., \& Kartini, I. A. N. (2020). Pengaruh Persepsi Harga, Citra Merek Dan Promosi Terhadap Keputusan Konsumen Dalam Memilih Jasa Gojek Di Kecamatan Taman Kabupaten Sidoarjo. Jurnal Ekonomi Manajemen, 5(2), 1-16.

Rivai, N. L., Tahir, A., \& Asnawi, M. A. (2018). Pelanggan Pembayaran Pajak Kendaraan Bermotor ( Sepeda Motor ) Pada Kantor Samsat Kota Gorontalo. Jurnal Ilmiah Manajemen Dan Bisnis, 1(1), 28-36.

Sangadji, E. M., \& Sopiah. (2013). Perilaku Konsumen: Pendekatan Praktis Disertai Himpunan Jurnal Penelitian. Yogyakarta: Penerbit Andi.

Sekaran, U., Roger, B., \& Yon, K. M. (2017). Metode Penelitian untuk Bisnis: Pendekatan Pengembangan-Keahlian. Jakarta: Salemba.

Setiowaty, T. R., \& Winarningsih. (2017). Pengaruh Harga, Kualitas Pelayanan dan Promosi Terhadap Keputusan Pembelian Konsumen Pada Kampoeng Steak Ketintang Surabaya. Jurnal Ilmu Dan Riset Manajemen, 6(April), 1-16. Retrieved from http://eprints.upnyk.ac.id/21084/

Shartanto, D., Djatnika, T., Ruhadi, \& Triyuni, N. N. (2017). Ritel Pengelolaan dan Pemasaran. Bandung: Alfabeta.

Simon, K. (2016). Pengaruh Kualitas Layanan Terhadap Kepuasan Pelanggan Surya Nalendra Sejahtera Tours \& Travel. Journal Of Management, 1(3), 15-26.

Sondakh, C. (2015). Kualitas Layanan, Citra Merek Dan Pengaruhnya Terhadap Kepuasan Nasabah Dan Loyalitas Nasabah Tabungan (Studi Pada Nasabah Taplus BNI Cabang Manado). Jurnal Riset Bisnis Dan Manajemen, 3(1), 19-32.

Sugiyono. (2012). Metode Penelitian Kuantitatif, Kualitatif dan R \& D.Bandung:Alfabeta. Metode Penelitian Kuantitatif, Kualitatif Dan $R \quad \& \quad$ D.Bandung:Alfabeta. https://doi.org/10.1017/CB09781107415324.004

Tjiptono, F. (2014). Pemasaran Jasa - Prinsip, Penerapan, dan Penelitiab. Bandung: Penerbit Andi. 
